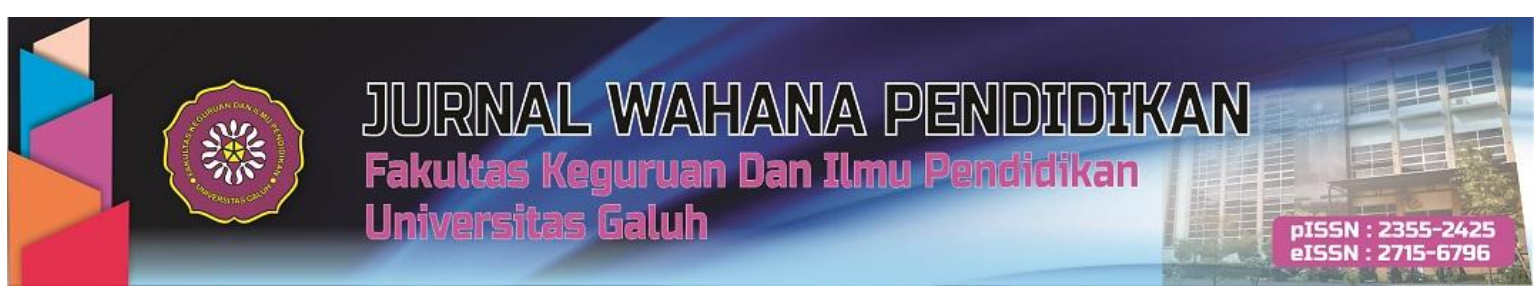

\title{
https://jurnal.unigal.ac.id/index.php/jwp
}

\section{PENINGKATAN KEMAMPUAN REPRESENTASI MATEMATIS SISWA MELALUI MODEL PEMBELAJARAN SCAFFOLDING}

\author{
Fitria Febriani ${ }^{1}$, Wahyudin ${ }^{2}$, Yoni Sunaryo ${ }^{3}$ \\ 1,3Universitas Galuh Ciamis, Jl. R. E. Martadinata No.150, Ciamis, Indonesia \\ 2Universitas Pendidikan Indonesia, \\ Email: febrianifitria09@gmail.com
}

\begin{abstract}
The purpose of this study is to find out the students' mathematical representation ability by means of the scaffolding learning model. This study used a quasi-experiment with nonequivalent control group design as the research method The data analysis technique was the parametric test $t$ 'test. the population was the VIII A to VIII D students of SMP Negeri 3 Ciamis, Indonesia. The samples were taken using the cluster random sampling technique. 30 students of the VIII B were the experimental class and 30 students of the VIII $C$ were the control class. The main instrument used was the test instrument which is an essay of mathematical representation ability test. The test was about cubes and blocks. The results showed that there were differences in increasing mathematical representation ability between students who taught by scaffolding model and students who taught by direct learning (Direct Instruction). The recommendation of this study is that the discussion part needs to be more effective because it was less conducive.
\end{abstract}

Keywords: Scaffolding Learning Model, Direct Learning (Direct Instruction), Mathematical Representation Ability

\begin{abstract}
ABSTRAK
Tujuan dari penelitian ini adalah untuk mengetahui gambaran tentang peningkatan kemampuan representasi matematis siswa yang menggunakan model pembelajaran scaffolding. Metode penelitian yang digunakan adalah Quasi Eksperimen, dengan desain nonequivalent control grup desain. Teknik analisis data menggunakan uji parametrik $t^{\prime}$ test. Populasi pada penelitian ini adalah siswa kelas VIII A sampai VIII D SMP Negeri 3 Ciamis. Pengambilan sampel menggunakan teknik cluster random sampling. Adapun sampel yang digunakan adalah kelas VIII B sebagai kelas eksperimen dengan jumlah 30 siswa dan kelas VIII C sebagai kelas kontrol dengan jumlah 30 siswa. Instrumen utama yang digunakan pada penelitian ini adalah instrumen tes yaitu soal tes kemampuan representasi matematis berbentuk uraian. Pokok bahasan yang disajikan sebagai bahan materi adalah kubus dan balok. Hasil penelitian ini adalah terdapat perbedaan peningkatan kemampuan representasi matematis antara siswa yang memperoleh pembelajaran scaffolding dengan siswa yang memperoleh pembelajaran langsung (Direct Instruction). Rekomendasi dari penelitian ini adalah pada tahap diskusi perlu diefektifkan karena kurang kondusif.
\end{abstract}

Kata Kunci : Model Pembelajaran Scaffolding, Pembelajaran Langsung (Direct Intruction), Kemampuan Representasi Matematis

Cara sitasi:

Febriani, F., Wahyudin \& Sunaryo, Y. (2020). Peningkatan Kemampuan Representasi Matematis Siswa Melalui Model Pembelajaran Scaffolding. Jurnal Wahana Pendidikan, 7(1), 39-44. 


\section{PENDAHULUAN}

Matematika merupakan ilmu yang menjadi pijakan bagi perkembangan ilmu pengetahuan dan teknologi modern, serta dapat memajukan daya pikir manusia. Matematika merupakan mata pelajaran yang diajarkan di setiap jenjang sekolah mulai dari sekolah dasar bahkan sampai dengan sekolah tinggi. Memahami dan mampu menerapkan konsep matematika dalam kehidupan seharihari sangatlah penting. Pentingnya penguasaan matematika terlihat pada Undang-Undang RI No. 20 tahun 2003 tentang SISDIKNAS Pasal 37 yang menegaskan bahwa mata pelajaran matematika merupakan salah satu mata pelajaran wajib bagi siswa pada jenjang pendidikan dasar dan menengah.

The National Council of Teacher Mathematic [NCTM] (2000) mengungkapkan bahwa terdapat lima standar kemampuan matematis yang harus dimiliki siswa dalam pembelajaran matematika yaitu pemecahan masalah, penalaran, komunikasi, koneksi, dan representasi. Salah satu kemampuan matematis yang disebutkan NCTM adalah kemampuan representasi. Yuningsih dan Rohaendi (2017) menyatakan bahwa representasi matematis merupakan bentuk ekspresi yang digunakan siswa yang dapat disajikan dalam bentuk penggambaran, penuangan pemikiran dan ide/gagasan yang mereka gunakan untuk menyelesaikan suatu permasalahan dan dapat direpresentasikan dengan objek, gambar, kata-kata atau simbol matematika.

Salah satu tujuan pendidikan nasional terhadap kemampuan representasi matematis tercermin dalam Peraturan Menteri Pendidikan Nasional RI Nomor 22 tahun 2006, dijelaskan bahwa "tujuan pembelajaran matematika di sekolah adalah agar siswa memiliki kemampuan mengkomunikasikan gagasan dengan simbol, tabel, diagram, atau media lain untuk menjelaskan keadaan atau masalah". Tujuan pembelajaran matematika tersebut termasuk kedalam salah satu indikator kemampuan representasi matematis sehingga diharapkan dengan penelitian ini dapat mencapai tujuan pendidikan nasional terutama pembelajaran matematika.

Menurut Sufairoh (2016), Pendekatan pembelajaran bedasarkan kurikulum 2013 menggunakan pendekatan saintifik yaitu proses pembelajaran yang dirancang agar peserta didik secara aktif mengonstruk konsep, hukum atau prinsip melalui tahapan-tahapan secara ilmiah. Informasi dapat berasal dari mana saja, kapan saja dan tidak tergantung pada guru. Oleh karena itu, kondisi pembelajaran diharapkan dapat mendorong peserta didik dalam mencari tahu dari berbagai sumber melalui observasi, diskusi, penelitian, dan lain sebagainya dan tentunya bukan hanya diberi tahu oleh guru.

Berdasarkan hasil wawancara dengan salah satu guru mata pelajaran matematika di SMP Negeri 3 Ciamis menyatakan bahwa model pembelajaran yang biasa diterapkan dalam pembelajaran di kelas adalah model pembelajaran langsung (Direct Intruction) dengan teacher centered approach yaitu guru menyajikan dan mentransfer informasi secara langsung dan terstruktur dengan metode ceramah. Tujuannya yaitu untuk penguasaan konsep dan keterampilan dasar. Permasalahanpermasalahan yang biasa disajikan oleh guru matematika di SMP Negeri 3 Ciamis bersifat dasar, sehingga menimbulkan kesulitan bagi beberapa siswa ketika mengahadapi soal kontekstual yang memerlukan pemahaman dan penguasaan konsep serta keterampilan yang lebih luas. Dalam menyelesaikan masalah kontekstual terdapat kemampuan representasi gambar, representasi persamaan matematis dan representasi kata atau teks tertulis. Kesulitan dalam menginterpretasi gambar menyebabkan kemampuan visualisasi beberapa siswa rendah, kesulitan dalam menentukan model atau persamaan matematis menyebabkan beberapa siswa sulit dalam menyelesaikan permasalahan berupa tekst tertulis.

Kemampuan setiap siswa itu berbeda-beda dan memiliki tingkat pemahaman yang berbedabeda, untuk itu sangat diperlukan model pembelajaran yang bisa memfasilitasi beberapa siswa tersebut untuk mengatasi kesulitan belajar. Oleh karena itu, kondisi pembelajaran dengan student centered diharapkan dapat mendorong peserta didik dalam mencari tahu dari berbagai sumber melalui observasi, diskusi, penelitian, dan lain sebagainya dan tentunya bukan hanya ditransfer oleh 
guru. Diharapkan siswa yang semula hanya menerima pembelajaran secara pasif dapat menjadi aktif dalam pembelajaran.

Menurut Vygotsky (Sunaryo dan Fatimah, 2018) "Scaffolding adalah pemberian bantuan kepada anak selama tahap-tahap awal perkembangannya dan mengurangi bantuan tersebut dan memberikan kesempatan kepada anak untuk mengambil alih tanggung jawab yang semakin besar segera setelah anak dapat melakukannya". Dalam konteks pembelajaran, penggunaan istilah scaffolding atau perancah ini tampaknya bisa dianggap relatif baru. Wood, dkk (Rahmawati F, 2016) juga menyatakan model pembelajaran scaffolding adalah model pembelajaran yang mana terdapat dukungan guru kepada peserta didik untuk membantunya menyelesaikan proses belajar yang tidak dapat diselesaikannya sendiri. Hal ini sejalan dengan pengertian ZPD menurut Vygotsky menyatakan, "Zone of Proximal Development (ZPD) merupakan jarak antara tingkat perkembangan aktual dengan tingkat perkembangan potensial. Tingkat perkembangan aktual tampak dari kemampuan seseorang untuk menyelesaikan tugas-tugas atau memecahkan berbagai masalah secara mandiri. Sedangkan tingkat perkembangan potensial tampak dari kemampuan seseorang untuk menyelesaikan tugas-tugas dan memecahkan masalah ketika di bawah bimbingan orang dewasa atau ketika berkolaborasi dengan teman sebayanya yang lebih berkompeten. (Cahyono, 2010).

Penelitian yang relevan dengan penelitian ini adalah penelitian yang dilakukan oleh Fitriana Rahmawati dari STKIP PGRI Bandar Lampung. Penelitian ini menemukan bahwa ada pengaruh penerapan model pembelajaran scaffolding terhadap hasil belajar matematika siswa kelas VIII semester ganjil SMP Negeri 30 Bandar Lampung, dan rata-rata hasil belajar matematika siswa yang belajar menggunakan model pembelajaran scaffolding lebih tinggi dibandingkan dengan yang tidak belajar menggunakan model pembelajaran scaffolding pada siswa kelas VIII SMP Negeri 30 Bandar Lampung.

Dalam satu kelas, tentu terdapat siswa yang memiliki tingakat kognitif yang tinggi, sedang dan rendah. Model pembelajaran scaffolding diharapkan dapat membantu siswa dalam mengatasi kesulitan belajar terutama dalam menyelesaikan masalah kontekstual yang berhubungan dengan representasi gambar, representasi persamaan dan ekspresi matematis, serta representasi kata atau teks tertulis. Oleh karena itu, tujuan dalam penelitian ini adalah untuk mengetahui gambaran tentang peningkatan kemampuan representasi matematis siswa yang memperoleh pembelajaran scaffolding.

Berdasarkan uraian yang telah dipaparkan sebelumnya, rumusan masalah yang akan diteliti dan dikaji lebih lanjut dalam penelitian ini yaitu apakah terdapat perbedaan peningkatan kemampuan representasi matematis antara siswa yang menggunakan model pembelajaran scaffolding dengan siswa yang menggunakan model pembelajaran langsung (Direct Instruction). Hasil penelitian ini diharapkan dapat memberikan gambaran mengenai peningkatan kemampuan representasi matematis siswa melalui model pembelajaran scaffolding.

\section{METODE PENELITIAN}

Metode yang digunakan dalam penelitian ini adalah metode eksperimen. Desain penelitian ini adalah Quasi Experimental Design, dengan bentuk the non-equivalent pretest-posttest control group design yang melibatkan dua kelas yaitu kelas eksperimen dan kelas kontrol. Setiap sampel diberi pretest dan posttest untuk mengetahui peningkatan kemampuan representasi matematis siswa. Desain dalam penelitian menurut Lestari dan Yudhanegara (2015), diilustrasikan sebagai berikut:

Kerangan:

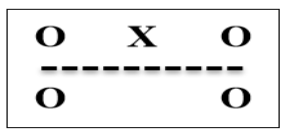

$0 \quad=$ Prestest dan Posttest

$\mathrm{X} \quad=$ Perlakuan dengan model pembelajaran scaffolding 
$--\quad=\quad=$ Pengambilan sampel secara acak kelas

Populasi dalam penelitian ini adalah siswa kelas VIII A-VIII D SMP Negeri 3 Ciamis pada semester genap tahun pelajaran 2018/2019 yaitu sebanyak 121 siswa. Sampel dalam penelitian ini sebanyak dua kelas yaitu kelas VIII B dengan jumlah 30 siswa sebagai kelas eksperimen yang akan diberi penerapan model pembelajaran Scaffolding dan kelas VIII C dengan jumlah 30 siswa sebagai kelas kontrol yang akan diberi penerapan model pembelajaran langsung (Direct Intruction). Pengambilan sampel menggunakan teknik cluster random sampling, hal ini karena setiap kelas mempunyai karakteristik yang sama dan guru yang sama. Sampel dalam penelitian ini sebanyak 60 siswa.

Instrumen yang digunakan dalam penelitian ini berupa soal tes kemampuan representasi matematis berbentuk soal subjektif (uraian) yang dikembangkan berdasarkan indikator representasi matematis. Uji peningkatan kemampuan representasi matematis siswa bertujuan untuk melihat perbedaan peningkatan kemampuan representasi matematis antara siswa yang memperoleh pembelajaran scaffolding dengan siswa yang memperoleh pembelajaran langsung (Direct Intruction). Setelah data hasil pretest dan posttest dianalisis, besarnya mutu peningkatan kemampuan representasi matematis siswa dihitung dengan menggunakan rumus gain ternormalisasi (N-Gain)..

\section{HASIL DAN PEMBAHASAN}

Berikut ini adalah sajian statistik deskriptif data skor N-Gain kemampuan representasi matematis siswa.

Tabel 1.

Statistik Deskriptif Data Skor N-Gain Kemampuan Representasi Matematis Siswa

\begin{tabular}{ccc}
\hline Statistik Deskriptif & \multicolumn{2}{c}{ Data Skor N-Gain } \\
& Eksperimen & Kontrol \\
\hline Jumlah Siswa & 30 & 30 \\
Skor Maksimum & 0,923 & 0,538 \\
Skor Minimum & 0,333 & 0,176 \\
Rata-rata & 0,635 & 0,326 \\
Median & 0,622 & 0,308 \\
Std. Deviasi & 0,168 & 0,098 \\
Varians & 0,028 & 0,010
\end{tabular}

Berdasarkan Tabel 1, diperoleh informasi bahwa rata-rata skor N-Gain kelas eksperimen adalah 0,635 , sedangkan skor rata-rata $\mathrm{N}-$ Gain kelas kontrol adalah 0,326. Merujuk pada tabel kriteria $\mathrm{N}$-Gain diperoleh kesimpulan bahwa kriteria peningkatan kemampuan representasi matematis siswa yang memperoleh model pembelajaran scaffolding termasuk kedalam kriteria sedang dan kriteria peningkatan kemampuan representasi matematis siswa yang memperoleh model pembelajaran langsung (Direct Intruction) termasuk kedalam kriteria sedang. Selanjutnya dilakukan uji normalitas data skor $\mathrm{N}$-gain untuk mengetahui apakah data berdistribusi normal atau tidak.

Tabel 2.

Hasil Uji Normalitas Data Skor N-Gain Kemampuan Representasi Matematis Siswa

\begin{tabular}{lccc}
\hline \multicolumn{1}{c}{ Faktor } & \multicolumn{3}{c}{ Shapiro-Wilk } \\
& Statistic & Df & Sig. \\
\hline Kontrol & 0,956 & 30 & 0,241 \\
Eksperimen & 0,950 & 30 & 0,168 \\
\hline
\end{tabular}

Berdasarkan tabel 2, hasil output uji normalitas data skor N-Gain menggunakan ShapiroWilk terlihat bahwa kelas eksperimen memiliki nilai signifikansi 0,168 >0,05 maka $H_{0}$ diterima, sehingga data skor $\mathrm{N}$-Gain kelas eksperimen berdistribusi normal. Kelas kontrol memiliki nilai signifikansi 0,241 >0,05 maka $H_{0}$ diterima, sehingga data skor N-Gain kelas kontrol berdistribusi normal. 
Dari hasil pengujian Shapiro-Wilk data skor N-Gain kemampuan representasi matematis, maka dapat disimpulkan bahwa data skor N-Gain kelas eksperimen dan kelas kontrol berdistribusi normal maka langkah selanjutnya adalah uji homogenitas.

Tabel 3.

Hasil Uji Homogenitas Data Skor N-Gain Kemampuan Representasi Matematis Siswa

\begin{tabular}{lccc}
\hline \multicolumn{4}{c}{ N-Gain Kemampuan Representasi Matematis } \\
\hline Levene Statistic & df1 & df2 & Sig. \\
10,710 & 1 & 58 & 0,002 \\
\hline
\end{tabular}

Tabel 3 menginformasikan bahwa hasil output uji homogenitas data skor N-Gain kemampuan representasi matematis siswa menggunakan uji Levene, terlihat bahwa nilai signifikansi $0,002<0,05$ maka maka $H_{0}$ ditolak, sehingga dari hasil pengujian uji Levene data N-Gain kemampuan representasi matematis berasal dari populasi yang mempunyai varians yang tidak sama atau tidak homogen. Selanjutnya, karena data kemampuan representasi kedua kelas berdistribusi normal tetapi tidak homogen, maka pengujian hipotesis dilakukan uji-t'.

Tabel 4.

Hasil Uji t' Data Skor N-Gain Kemampuan Representasi Matematis Siswa

\begin{tabular}{ccccc}
\hline \multicolumn{2}{c}{ Independent Samples Test } & \multicolumn{3}{c}{ t-test for Equality of Means } \\
& t & df & Sig. (2-tailed) \\
\hline N-Gain & $\begin{array}{c}\text { Equal variances } \\
\text { not assumed }\end{array}$ & 8.691 & 46.730 & .000
\end{tabular}

Dari tabel 4, diperoleh hasil perhitungan uji perbedaan dua rata-rata uji-t' data skor N-Gain kelas eksperimen dan kelas kontrol dengan nilai signifikansi $0,000<0,05$ maka $H_{0}$ ditolak dan $H_{1}$ diterima, artinya terdapat perbedaan peningkatan kemampuan representasi matematis antara siswa yang memperoleh pembelajaran scaffolding dengan siswa yang memperoleh pembelajaran langsung (Direct Intruction).

Penelitian dilaksanakan selama 6 kali pertemuan, pada pertemuan pertama digunakan untuk pretest. Soal pretest terdiri dari 5 butir soal berbentuk uraian yang telah memenuhi kriteria validitas dan reliabilitas melalui perhitungan dengan menggunakan Softwere SPSS. Selanjutnya kegiatan pembelajaran dilakukan selama 4 kali pertemuan. Pembelajaran di kelas eksperimen memperoleh pembelajaran scaffolding sedangkan dikelas kontrol peneliti memperoleh pembelajaran langsung (Direct Intruction). Proses pembelajaran di kelas eksperimen pada pertemuan pertama siswa belum terbiasa dengan pembelajaran yang diberikan sehingga siswa masih terlihat kurang aktif dan kegiatan diskusi belum berjalan dengan baik. Pertemuan pertama dijadikan kegiatan adaptasi terhadap pembelajaran yang dilakukan. Namun setelah guru menjelaskan dan memberi arahan tentang model yang akan digunakan dan mengajak siswa untuk ikut berperan aktif dalam proses pembelajaran sehingga pada pertemuan selanjutnya siswa sudah mulai terbiasa dengan pembelajaran yang dilakukan, mulai aktif dalam pembelajaran, dan diskusi kelompok mulai berjalan dengan baik meskipun tidak semua siswa ikut berperan aktif ada saja siswa yang masih terlihat pasif dalam pembelajaran. Setelah selesai proses pembelajaran selama 4 kali pertemuan, selanjutnya siswa diberikan soal posttest. Tes dilakukan pada kelas eksperimen dan kelas kontrol dengan soal yang sama. Butir soal yang digunakan berbentuk subjektif (uraian) sebanyak 5 butir soal. Posttest diberikan dengan tujuan untuk mengetahui perbedaan peningkatan kemampuan representasi matematis setelah siswa melaksanakan pembelajaran selama empat kali pertemuan.

Selama proses pembelajaran matematika dengan menggunakan model pembelajaran scaffolding, peneliti mendapati beberapa kendala walaupun peneliti telah melakukan banyak hal untuk meminimalisir kendala-kendala tersebut. Kendala pada kelas eksperimen diantaranya: pembelajaran dengan metode kelompok menjadi hal baru sehingga mereka banyak ngobrol, merasa ragu-ragu dalam berkelompok dan mereka lama dalam menempatkan tempat duduk sesuai kelompoknya sehingga waktu yang dibutuhkan cukup lama sehingga pada pertemuan 1 dan 2 tidak sampai pada simpulan materi karena waktu sudah habis, sering gaduh dan beberapa siswa bermain sendiri sehingga situasi di dalam kelas kurang kondusif. Namun guru tetap memberikan arahan, 
penjelasan dan juga memberikan semangat serta membantu siswa mempelajari materi semaksimal mungkin.

Model pembelajaran scaffolding memberikan banyak manfaat diantaranya siswa yang tadinya belajar secara pasif menjadi aktif, dapat memotivasi dan meningkatkan minat belajar siswa, dengan belajar berkelompok siswa diarahkan untuk saling berbagi pengetahuan, dan menjalin komunikasi dengan baik dengan teman. Selain itu, pemilihan materi yang bersifat kontekstual mengakibatkan siswa bisa menghubungkan materi dengan kehidupan sehari-hari sehingga pembelajaran tidak hanya penguasaan konsep dan mempelajari keterampilan dasar saja. Maka dengan begitu kemampuan representasi matematis siswa semakin meningkat karena siswa dibiasakan mengubah masalah kedalam bentuk representasi lain baik itu representasi gambar, representasi persamaan matematis, maupun representasi kata atau teks tertulis.

\section{KESIMPULAN}

Berdasarkan uraian hasil dan pembahasan yang telah dikemukakan diperoleh kesimpulan bahwa terdapat perbedaan peningkatan kemampuan representasi matematis antara siswa yang memperoleh pembelajaran scaffolding dengan siswa yang memperoleh pembelajaran langsung (Direct Instruction).

\section{REKOMENDASI}

Rekomendasi dari penelitian ini adalah bagi peneliti selanjutnya, penelitian ini dapat dilanjutkan untuk melihat perbedaan peningkatan pembelajaran dengan model pembelajaran scaffolding dalam meningkatkan kemampuan matematis lainnya, seperti kemampuan pemahaman, komunikasi, koneksi, dan pemecahan masalah.

\section{UCAPAN TERIMAKASIH}

Peneliti mengucapkan terimakasih kepada seluruh civitas Program Studi Pendidikan Matematika Fakultas Keguruan dan IImu Pendidikan Universitas Galuh, Drs. H. Aip Syaripudin, M.M., selaku Kepala SMP Negeri 3 Ciamis yang telah memberikan izin penelitian kepada penulis, Yanti Nopianti, S.Pd., selaku Guru mata pelajaran matematika kelas VIII serta guru-guru dan staf SMP Negeri 3 Ciamis yang telah memberikan bimbingan, arahan dan bantuan kepada penulis dalam melakukan penelitian.

\section{DAFTAR PUSTAKA}

Cahyono, N.A. (2010). Proses Scaffolding untuk mencapai Zone of Proximal Development (ZPD) Peserta Didik dalam Pembelajaran Matematika. Seminar Nasional Matematika dan Pendidikan Matematika Yogyakarta (442-448). Tersedia di: http://eprintts.uny.ac.id

National Council of Teachers of Mathematics [NCTM]. (2000). Principles and Standards for School Mathematics. Tersedia di: http://www.nctm.org/Standards-andPositions/Principles-and-Standards/

Rahmawati, F. (2016). Pengaruh Penerapan Model Pembelajaran Scaffolding Terhadap Hasil Belajar Matematika Pada Siswa Kelas VIII Semester Ganjil SMP Negeri 30 Bandar Lampung. Jurnal Penelitian LENTERA STKIP Bandar Lampung Vol.1 146-154. Tersedia di: www.jurnal.stkippgribl.ac.id/articl.

SISDIKNAS. (2003). UU No. 20 Tahun 2003 tentang Sistem Pendidikan Nasional. Jakarta. Tersedia di: http://www.komisiinformasi.go.id/regulasi/dwonload/id/101\&ved

Sufairoh. (2016). Pendekatan Saintifik dan Model Pembelajaran K-13. Jurnal Pendidikan Profesional, 5(3), 120. Tersedia di: www.jurnalpendidikanprofesional.com $>>$

Sunaryo \& Fatimah. 2018. Implementasi Pendekatan Kontekstual pada Model Pembelajaran Scaffolding. Jurnal Penelitian Pendidikan dan Pengajaran Matematika, 4(2) 87-96.

Yuningsih, A. S.,\& Rohaendi, S. (2017). Penerapan Model Pembelajaran Jigsaw untuk Meningkatkan Kemampuan Representasi. Jurnal Biormatika, 4(1), 16-23. Tersedia di: ejournal.unsub.ac.id/index.php/FKIP/article/download/8/7/. 